\title{
HOW MUCH INFORMATION DO YOU NEED? INTERACTION OF INTUITIVE PROCESSING WITH EXPERTISE
}

\author{
Vladimíra ČAVOJOVÁ, Róbert HANÁK \\ Institute of Experimental Psychology, Slovak Academy of Sciences \\ Dúbravská cesta 9, 84104 Bratislava, Slovak Republic \\ E-mail: vladimira.cavojova@savba.sk
}

\begin{abstract}
Intuition is usually seen as fast, automatic, high processing capacity, yet only few studies focused directly on the connection with the amount of information search. In this paper we present two studies examining two different domains (financial and recruiting) and employing different manipulations (time stress and instruction). The main aim of both studies was to examine whether preference for intuition (as cognitive style) would lead to less information search with respect to expert and non-expert population, with experience as moderator affecting intuitive people more in terms of searching for less information. Generally, our results indicate that situational manipulations, such as inducing time stress or giving instruction to think intuitively, affect information search more than preferred cognitive style and that it is necessary to examine intuition in context-specific tasks as the experience plays a crucial role in the searching information when making decisions.
\end{abstract}

Key words: intuition, information search, expertise

Intuition is often associated with sudden revelation of solution to the problem at hand. It is connected with unconscious processing of information (Dijksterhuis, Nordgren, 2006), relying on experience (Klein, 1998), even experience being transformed into routines (Betsch, Haberstroh, 2005), and processes of Type 1 (e.g., Evans, 2010; Stanovich, 2006, 2011), which are described

Acknowledgment: This research was supported by a grant from Slovak Ministry of Education VEGA 2/0064/13: Decision Making of Experts: Using Intuition for Solution of Strategic Tasks awarded to Vladimíra Čavojová.

The authors would like to thank their participants for taking part in the study, Mgr. Katarína Vicenová for help with collecting data in Study 2 and Eva Ballová Mikušková, PhD. for proofreading the first draft of the manuscript and helpful comments. as quick and automatic. For example, Evans (2010) argues that if we roughly equate intuition with the distinction between Type 1 (intuitive) and Type 2 (analytic) processes in contemporary dual processes of thinking and reasoning, then we can say that intuition is quick, is associated with feeling of confidence, can reflect large amount of information processing, and is based on past experience and learning. Fast Type 1 (intuitive) processes provide quick default solution to a problem at hand. Type 2 (deliberative) processes can either accept the intuitive solution or intervene with more explicit Type 2 deliberation and reasoning. When this kind of intervention happens, the default intuitive solution can be overridden. Checking and overriding default intuitive solution is hypothesized to be affected by cognitive styles (e.g., intuitive/deliberative, Betsch,

DOI: $10.21909 /$ sp.2014.02.652 
2004; rational/experiential, Epstein, 2003; etc.), or by newly added element into dual-process theories - reflective mind (Stanovich, 2011)

Recently, there is much debate about what characteristics distinguish Type 1 and Type 2 processes in contemporary dual-system theories (Evans, Frankish, 2009). In opposition to the heuristics and biases program, some authors tend to also highlight the positive aspects of intuition (e.g., Gigerenzer, 2007; Hogarth, 2001; Myers, 2002; Ballová Mikušková, 2013; Čavojová, 2013). There is an agreement that intuition is fast, automatic, high processing capacity and low effort (Evans, 2009), yet only few studies focused directly on the connection of these supposedly fast processes with the amount of information searching, even though there is an implicit assumption that intuition (Type 1) should result in a solution with less information than deliberation (Type 2 processes) - a view that is reflected in Less is more or Take the best heuristic (Gigerenzer, 2007). Less is more means that in complex and unpredictable environment, better results can sometimes be achieved by relying on fewer (more valid) predictors when making decision. Knowing predictive validity is closely connected with expertise (Shanteau, 1992a) and experts use fewer but more relevant pieces of information (Shanteau, 1992b; Garcia-Retamero, Dhami, 2009; Hanák, Sirota, Juanchich, 2013).

One of the researchers, who explicitly associated intuition with the amount of information taken into account in making a decision, was Westcott $(1961,1966)$. He defined intuitive thinking, based on the behavioral data, as a special case of inference or induction in which the "gap" between evidence and conclusion is unusually large. In an ex- periment involving a series of problems (Westcott, 1961), in which participants could decide whether they want to see greater or lesser amounts of relevant information, he found reliable individual differences. These differences were both in the tendency of individuals for shorter (or longer) intuitive leaps, as well as in the tendency to do so accurately, and thus, four types of participants emerged based on their tendency for intuitive leaps and on the accuracy of their solutions. Furthermore, the results of his study showed that the amount of information requested did not predict the participant's success in solving the problem.

In this case the intuition per se was operationalized as the amount of information search. However, will the connection between the preference for intuition and the reliance on lesser amounts of information for making a decision hold true if we first identify intuitive people and then study the differences between their information search (and whether it affects the decision result)? For example, Sarmány-Schuller (2010) studied the intuitive/analytical cognitive style (self-reported) in relation to the performance in decision tasks under time pressure. He found that intuitive participants solved more tasks under time pressure than analytical ones, but tackling more tasks was not related to the correctness of the solution. However, to our knowledge, there are no studies as of now, examining the implicit assumption that people identifying themselves as intuitive will search for and rely on less information during their decision making. Therefore, the main aim of this paper is to test the assumption that intuition (either as a characteristic of an individual or a situation) leads people to base their decisions on less amount of information and 
also test if this relationship is moderated by expertise (expertise associated with knowledge of more valid clues).

\section{OVERVIEW OF TWO STUDIES}

We examined the effect of intuition on information search in two ways - 1) by identifying the participants' preferences for intuitive/deliberative decision making and focusing on those most intuitive, and 2) by inducing intuition, either by time stress (Study 1) or instruction (Study 2), as these are two most common ways of manipulating intuitive/deliberative mode of processing information (Evans, 2009; Hausmann, Horstmann, Ryf, 2010). Next, in both studies we examined the relationship of expertise (as predictor or moderator) and information processing.

According to Klein (1999), intuition is just expertise based on experience and higher expertise leads, among other things, to better recognition of more valid clues. Thus, we hypothesized that expertise together with intuition would affect the amount of information needed when making a decision. Specifically, we expected that the preference for intuitive processing of information would predict the number of opened clues better when it is moderated by expertise.

Both studies address the question, whether intuition leads to less information search and if it is moderated by expertise. The Study 1 examines, whether 1) time stress leads to intuitive processing, 2) intuitive processing leads to less information search, 3 ) intuitive people engage in less information search regardless on the time stress, 4) expertise moderates information search. Study 2, with a different sample of experts, then examined whether 1) explicit instruction will lead to intuitive processing, 2) intuitive processing leads to less information search, 3) experts will use their intuition differently than nonexperts, 4) expertise moderates information search.

\section{STUDY 1}

\section{INTUITION AND \\ INFORMATION SEARCH UNDER TIME STRESS VS. NO TIME STRESS}

Study 1 focused on comparing the evaluation of fictional enterprise under two conditions - under time stress ( 3 minutes) and with no time stress, with the effect of expertise treated as the moderator. We assumed that intuitive people compared to deliberative people would rely on less information in both conditions and expertise would moderate the relationship between intuition and the number of opened clues.

\section{PARTICIPANTS AND PROCEDURE}

A total of 176 external students from the College of Economy and Management of Public Service in Bratislava (average age of 31.3 years, 63 men and 113 women) participated in the study. We used the within-participants experimental design, i.e. each participant first evaluated a fictional business under time stress condition and then without time stress. Participants were divided according to their work experience into three groups. The first group $(n=44)$ did not have any work experience (measured by years spent at work). Second group $(\mathrm{n}=58)$ had experience but not in financial or managerial area. Third group $(n=56)$ was classified as experts, working in the financial sector (accountants, financial managers or high level managers) for 12.3 years. 


\section{MATERIALS}

\section{Enterprise Task}

We constructed an "enterprise task" as a complex decisional problem, which is described in 25 economic characteristics/clues (e.g., product appearance, potential sale, etc.), which were taken from the evaluation criteria of the Canadian Association for Enhancing of Business. These characteristics/ clues have different predictive validity in terms of their ability to predict future success of a given enterprise (Åstebro, Elhedhli, 2006). The task was coded in such a way that of the 25 clues, 22 were described positively and only 3 negatively (potential sale, profitability and investment return). However, these three clues were crucial for correct evaluation of future success (so that the correct answer is failure of the enterprise).

Participants had to ascribe percentual weight to each of the characteristics (according to the subjective importance for the participant); the clue (written description of the characteristic) was displayed only after filling in the number of percentual weight. At the end of the task, participants evaluated the enterprise by an overall mark on a scale from zero to $10(0$ meaning certain failure and 10 certain success).

The main dependent variable in this study was not, however, the correct answer (the failure of the enterprise), but the amount of information search expressed by the number of opened clues. We tested the assumption that participants identified as intuitive by the Preference for Intuition/Deliberation (Betsch, 2004) self-report inventory would rely on less information, which should be most obvious in the time stress condition designed to induce intuitive mode of processing.

\section{Preference for Intuition and Deliberation}

The PID is a self-report inventory (Betsch, 2004), which defines intuition as a basic decision mode that uses affect as a decision criterion. Deliberation is defined as a decision mode following explicit evaluation, beliefs, and reasons. Intuition and deliberation are considered to be two dimensions, not endpoints of one bipolar dimension (Betsch, 2004). The two independent subscales of PID measure an individual, stable preference for intuition (PID-I), and a preference for deliberation (PID-D). The scale comprises of 18 items, 9 indicating PID-I (e.g., "My feelings play an important role in my decisions"), and 9 items indicating PID-D (e.g., "I prefer making detailed plans rather than leaving things to chance"). Responses were given on a 5point scale, with higher score in each subscale indicating higher preference for intuition and deliberation. Internal consistency of the two subscales of PID was verified in the Slovak sample $(N=750)$. Cronbach's $\alpha$ was 0.827 for PID-Deliberation and 0.738 for PID-Intuition (Ballová Mikušková, Hanák, Čavojová, under review).

\section{RESULTS}

Firstly, we tested the assumption that all intuitive participants (without being assigned into non-expert or expert group) would engage in less information search by correlational analysis of preference of intuition with the number of opened clues. Results for the whole sample showed, in fact, no or minimal correlation between preference for intuition and number of opened clues, in 
both, the condition of time stress $(r=-.093$; $\mathrm{p}=.247)$ and in no stress condition $(\mathrm{r}=-.039$; $\mathrm{p}=.631)$. Regression analysis with preference for intuition as a predictor was insignificant. These results were similar for all three groups, but the trend for opening fewer clues for PID intuitive respondents was observable with increasing years of working in financial and managerial domain. Based on these analyses, we concluded that intuitive or deliberative score in PID alone does not affect the number of opened clues.

Next, we used the t-test for comparing intuitive and deliberative participants in the number of opened clues first in the condition of time stress and then in no time stress condition. Results revealed a difference in information search between conditions $(\mathrm{t}=$ -8.043; $p=.000)-$ participants engaged in more information search in the condition of no time stress ( 12.35 vs. 15.6 opened clues). However, no difference was found between intuitives and deliberatives in the number of opened clues in either condition (Table 1). In line with the results of correlational analysis, in both conditions deliberative people (those, who scored in the upper quartiles in preference for deliberation and lower quartile in preference for intuition) opened more clues than the intuitive ones (though the difference of one clue was not significant).

Because results showed no effect of preference for intuition/deliberation on information search, we also analyzed age and work experience measured by years in a field. Age and years of work positively correlated more with the number of opened clues in both conditions than with PID-I or PID-D, but only in time stress condition (Table 2).

Because of stronger correlation with age and years of experience, we applied the regression analysis for each of the following variables as single predictors (age, years of experience, PID-I and PID -D). Neither PID-I, nor PID-D had significant effect in any condition. In condition of time stress, age had a

Table 1. Comparison of intuitive and deliberative types in the number of opened clues in two conditions (time stress vs. no time stress)

\begin{tabular}{|c|c|c|c|c|c|c|}
\hline & $\begin{array}{l}\text { Preference } \\
\text { PID }\end{array}$ & $\mathrm{N}$ & M & $\mathrm{SD}$ & $\mathrm{t}$ & $\mathrm{p}$ \\
\hline \multirow{2}{*}{$\begin{array}{l}\text { No of opened clues } \\
\text { (time stress) }\end{array}$} & deliberative & 38 & 13.21 & 5.19 & \multirow{2}{*}{0.528} & \multirow{2}{*}{0.599} \\
\hline & intuitive & 36 & 12.58 & 5.02 & & \\
\hline \multirow{2}{*}{$\begin{array}{l}\text { No of opened clues } \\
\text { (no time stress) }\end{array}$} & deliberative & 38 & 16.95 & 6.14 & \multirow{2}{*}{1.357} & \multirow{2}{*}{0.178} \\
\hline & intuitive & 36 & 15.03 & 6.02 & & \\
\hline
\end{tabular}

Legend: $\mathrm{M}=$ mean, $\mathrm{SD}=$ standard deviation, $\mathrm{t}=\mathrm{t}$-test, $\mathrm{p}=$ statistical significance

Table 2. Correlation between age, years at work and number of opened clues in the two conditions

\begin{tabular}{|l|l|l|}
\hline $\mathrm{N}=158$ & Age & Years at work \\
\hline $\begin{array}{l}\text { Number of opened clues } \\
\text { (under time stress) }\end{array}$ & $\mathrm{r}=.162(\mathrm{p}=.042)$ & $\mathrm{r}=.181(\mathrm{p}=.023)$ \\
\hline $\begin{array}{l}\text { Number of opened clues } \\
\text { (no time stress) }\end{array}$ & $\mathrm{r}=.134(\mathrm{p}=.094)$ & $\mathrm{r}=.130(\mathrm{p}=.104)$ \\
\hline
\end{tabular}


small effect $(\beta=.162, t(156)=2.05, p=.042)$, explaining only very small part of the variance $\mathrm{R}^{2}=.026, \mathrm{~F}(1,156)=4.2, \mathrm{p}=.042$. In the time stress condition, years of experience could be used as a predictor as well $(\beta=.181$, $\mathrm{t}(156)=2.3, \mathrm{p}=.023)$, but again, explaining only a tiny level of the variance $\mathrm{R}^{2}=.026$, $F(1,156)=5.26, p=.023$. This effect vanished with no time stress. We compared all respondents according to the level of experience in finance and management and their clues opening.

Table 3. Moderation analyses in Study 1 - all participants, experts under time stress and no time stress conditions

All participant: moderation analysis under time stress

PID-I $=$ predictor. Years in field $=$ moderator. Number of opened clues under time stress $=$ outcome. Model parameters: $\mathrm{R}^{2}=.1042 ; \mathrm{p}=.0061 ; \mathrm{n}=156 ; \mathrm{R}^{2}$ increase due to interaction $\mathrm{R}^{2}=.0658 . \mathrm{p}=.0011$

\begin{tabular}{|l|c|c|c|c|}
\hline & Coefficient & SE & $\mathrm{t}$ & $\mathrm{p}$ \\
\hline Intercept - () & 12.920 & .376 & 32.489 & .000 \\
\hline Condition - X (PID-I) & -.052 & .070 & -.745 & .457 \\
\hline & & & & \\
\hline Moderator - M (years in field) & .113 & .048 & 2.780 & .020 \\
\hline Interaction X x M & -.031 & .010 & -3.178 & .002 \\
\hline
\end{tabular}

Expert group: moderation analysis under time stress

PID-I = predictor. Years in field $=$ moderator. Number of opened clues under time stress $=$ outcome. Model parameters: $\mathrm{R}^{2}=.2469 ; \mathrm{p}=.0106 ; \mathrm{n}=54 ; \mathrm{R}^{2}$ increase due to interaction $\mathrm{R}^{2}=.1583 . \mathrm{p}=.0021$

\begin{tabular}{|l|c|c|c|c|}
\hline & Coefficient & $\mathrm{SE}$ & $\mathrm{t}$ & $\mathrm{p}$ \\
\hline Intercept - () & 12.290 & .585 & 21.497 & .000 \\
\hline Condition - X (PID-I) & -.207 & .135 & -1.534 & .131 \\
\hline & & & & \\
\hline Moderator - M (years in field) & .137 & .063 & 2.181 & .034 \\
\hline Interaction X x M & -.046 & .014 & -3.274 & .002 \\
\hline
\end{tabular}

Expert group: moderation analysis without time stress

PID-I $=$ predictor. Years in field $=$ moderator. Number of opened clues without time stress $=$ outcome. Model parameters: $\mathrm{R}^{2}=.1661 ; \mathrm{p}=.0047 . \mathrm{n}=54 ; \mathrm{R}^{2}$ increase due to interaction $\mathrm{R}^{2}=.1395 . \mathrm{p}=.0056$

\begin{tabular}{|l|c|c|c|c|}
\hline & Coefficient & $\mathrm{SE}$ & $\mathrm{t}$ & $\mathrm{p}$ \\
\hline Intercept - () & 15.946 & .830 & 19.208 & .000 \\
\hline Condition - X (PID-I) & -.182 & .028 & -1.093 & .279 \\
\hline & & & & \\
\hline Moderator - M (years in field) & .085 & .083 & 1.028 & .309 \\
\hline Interaction X x M & -.059 & .018 & -3.179 & .002 \\
\hline
\end{tabular}

Legend: $\mathrm{SE}=$ standard error, $\mathrm{R}^{2}=\mathrm{R}$ squared, $\mathrm{p}=$ statistical significance 
Because we found no effect of PID score on the number of opened clues in any condition, and participants' age or years of experience explained just a minimal variance, we decided to examine if the intuition effect on information search could be moderated by expertise (operationalized as the number of years in a field). PID-D with expertise as a moderator was also examined, but did not show significant predictive capacity in any model, whereas the PID-I did in the group of all participants, as well as in the group of experts in both conditions (Table 3 ), but not in the group with other than financial working experience $(n=58)$. In the condition of time stress, the level of expertise was the most significant moderator in all models, and the interaction between expertise and PID intuitive score was also significant.

In the condition without time stress, we did not expect as strong of an effect as under time stress and the results confirmed our expectations. Expertise (number of years in the field) was not a significant moderator but the interaction between expertise and PID-I was significant (Table 3).

\section{DISCUSSION}

The preference for intuition, as the only explaining variable, has no effect in terms of engaging in less information search. Other variables, such as time stress, testing atmosphere, design of the experiment, or amount of experience in the task domain (business), could also have some effect but results from moderation analysis show that the failure to find differences between intuitive and deliberative people without financial experience in terms of their information search tendency could be explained by expertise. Years in financial or managerial field, as one of the characteristics of expertise, are a significant moderator in the relationship between preference for intuition and the number of opened clues for the evaluation of a business. Those respondents who were intuitive opened fewer clues than deliberative ones, but having years of experience in finance or management "allowed" them to open even fewer clues than being solely intuitive. This relationship is stronger in the time stress condition. It is important to note, that only higher age and work experience in different, not financial or managerial field lead to exactly the opposite direction, which means opening in fact more clues! In other words, participants who have work experience (second group, $\mathrm{n}=58$ ), but not in finance, opened with higher age or years of work experience more clues. Interaction between preference of intuition and years of experience in finance extends by $14 \%$ under time stress and $16 \%$ without time stress explained variability in information search. Because information search showed an increasing trend with the level of specific knowledge (years in a field), in Study 2 we examined professionals from other fields.

It is necessary to point out the possible problem created by inducing intuition through time reduction, which causes significant time stress. It can result in several drawbacks, such as restricted range of options taken into account, attributing higher importance to negative information, inadequate coping strategies, such as neglecting important facts, bolstering of preferred option, etc. (Zakay, 1993). It is highly possible that time reduction created only stress, but no intuitive processing, especially in groups of respondents with no practical and 
little theoretical experience and knowledge. Similar conclusions are provided by Sarmány-Schuller and Bukvajová (2013), who studied decision making under time stress in relation to the reflexivity - impulsivity cognitive styles, while manipulating information uncertainty/certainty. As time stress increases in the certainty condition, participants tend to engage in more impulsive decision-making, which is characterized by higher speed, but lower accuracy. These results lead us, too, to some modifications in Study 2 regarding inducing intuitive processing.

\section{STUDY2}

\section{INTUITION AND INFORMATION SEARCH IN INTUITIVE VS. RATIONAL CONDITION}

In the next study, we decided to test several assumptions that were not addressed in the previous study. Firstly, we wanted to confirm the results from Study 1 with PID-I as a predictor, expertise (number of assigned job applicants) as a moderator and their effect on information search. Therefore, in Study 2 we again tested professionals but in a different domain (recruiting) and compared their intuitive performance with non-experts. Secondly, we speculated that time stress is not a suitable tool for inducing intuition and it could deteriorate the performance (Zakay, 1993), therefore, in this study we induced intuition by explicit instruction (Hausman et al., 2010), and we checked the success of this manipulation by measuring time (and thus also comparing it to the previous study). Thirdly, we used similar context-specific task, but not from an economics, but human resources domain.

\section{PARTICIPANTS AND PROCEDURE}

Sixteen professional HR specialists ( 3 men and 13 women) with mean age $30.5(25-43$ years) and 16 non-experts ( 8 men and 8 women) with mean age 26.06 ( $22-32$ years) participated in Study 2. Experts had an average of 6 years of experience and about 1112 interviews with job applicants. Nonexperts were mostly university students or young working adults with no experience with hiring applicants for job.

Study 2 employed a within-participants design, so each participant evaluated one job applicant in the intuitive and one in the analytic condition. The order of conditions was counterbalanced for both groups of participants (experts and non-experts) and time was measured in both conditions. We also conducted between-subject comparisons to determine if performance in the intuitive and deliberative conditions differed depending on whether these conditions were done first or second.

The main dependent variables in Study 2 were again the number of opened clues and the correct evaluation of job applicant. The whole task together with filling in additional questionnaires took about one hour and no incentives were given to participants.

\section{Materials}

In Study 2 we used the same PID scale as in the previous study, but the main experimental task differed. Instead of evaluating one future fictional enterprise in two different conditions, the participants evaluated two different job applicants in the condition of intuitive decision-making and in the condition of rational-decision making. Intuition 
vs. rationality was manipulated through explicit instruction ${ }^{1}$.

\section{Hiring task}

Two job applicants were constructed in the same way as fictional enterprise; they were described by 25 characteristics of different predictive validity and participants had to indicate by writing an " $X$ " into a cell that they want to see the content of a given characteristics (clue). On the basis of a previous study (Hanák, 2010), we identified the three most predictive characteristics and those were coded negatively (same as in the enterprise task in the previous study). Therefore, to correctly evaluate the job applicant, one had to identify the most predictive clues and modify his or her evaluation toward a more negative one. All clues were written as either definitely positive or negative, but they were formulated not to sound too extreme (instead of "job applicant is very poor in cognitive ability" there was "he did not do well in tests of intelligence, creativity and memory").

The second part of the job-applicant evaluation task was evaluation of weight (importance) each participant placed on various characteristics (clues). After each evaluation the participants also had to indicate, on a simple 5-point scale, to what extent their judgment was intuitive or rational.

\footnotetext{
${ }^{1}$ Instruction for intuitive condition read: Please, decide intuitively with the least amount of opened clues.

Instruction for deliberative condition read: Please, decide as rationally as possible and use as many clues as you need.
}

\section{RESULTS}

Firstly, we checked if there was a difference between the intuition condition being administered first or second. We analyzed the difference in information search in each condition (intuitive vs. deliberative) separately for experts and non-experts and in both groups we found a significant difference in the amount of opened clues (Table 4). Moreover, experts differed from non-experts in the amount of information search, but only in the intuition condition $(\mathrm{t}=$ $-4.019, p=.000)$ - experts opened on average 3.4 clues in contrast with an average of 5.1 opened by non-experts. In the rational condition, the expert group opened three times as many clues as in the intuitive condition $(\mathrm{M}=9.06, \mathrm{SD}=2.24)$ and the nonexpert group opened twice as many clues as in the intuitive condition $(\mathrm{M}=10.88$, $\mathrm{SD}=4.54$ ).

Subsequently, we analyzed correlations between participants' preferences in PID and the amount of information search (Table 5). Generally, we found a tendency of nonexpert participants with preference for intuition to engage in less information search and also a tendency of non-expert participants with preference for deliberation to engage in more information search, as was hypothesized. There was no significant relationship between preference for intuition/ deliberation and information search in the expert sample, only a slight tendency for intuitive experts to engage in less information search.

Moderation analysis was used to find an effect of combination of intuition and expertise on the number of opened clues. In this case, we defined expertise as the num- 
Table 4. Difference in information search between experts and non-experts in intuitive and deliberative conditions (Study 2)

\begin{tabular}{|l|c|c|c|c|c|c|}
\hline & \multicolumn{2}{|c|}{$\begin{array}{c}\text { no. of opened clues } \\
\text { (intuition condition) }\end{array}$} & \multicolumn{2}{c|}{$\begin{array}{c}\text { no. of opened clues } \\
\text { (rational condition) }\end{array}$} & & \\
\hline & $\mathrm{M}$ & $\mathrm{SD}$ & $\mathrm{M}$ & $\mathrm{SD}$ & $\mathrm{t}$ & $\mathrm{p}$ \\
\hline experts & 3.38 & .62 & 9.06 & 2.24 & -11.241 & .000 \\
\hline non-experts & 5.13 & 1.63 & 10.88 & 4.54 & -5.204 & .000 \\
\hline
\end{tabular}

Table 5. Correlation between preference for intuition/deliberation (PID) with amount of information search in experts and non-experts (Study 2)

\begin{tabular}{|c|c|c|c|}
\hline & & $\begin{array}{l}\text { no. of opened clues in } \\
\text { intuitive condition }\end{array}$ & $\begin{array}{l}\text { no. of opened clues in } \\
\text { rational condition }\end{array}$ \\
\hline \multirow{4}{*}{$\begin{array}{l}\text { experts }-\mathrm{HR} \\
\text { specialists }\end{array}$} & $\begin{array}{l}\text { no. of opened clues } \\
\text { in intuitive condition }\end{array}$ & & $\mathrm{r}=.464(\mathrm{p}=.070)$ \\
\hline & $\begin{array}{l}\text { no. of opened clues } \\
\text { in rational condition }\end{array}$ & $\mathrm{r}=.464(\mathrm{p}=.070)$ & \\
\hline & PID-I & $\mathrm{r}=-.055(\mathrm{p}=.838)$ & $\mathrm{r}=.086(\mathrm{p}=.751)$ \\
\hline & PID-D & $\mathrm{r}=.283(\mathrm{p}=.288)$ & $\mathrm{r}=-.232(\mathrm{p}=.387)$ \\
\hline \multirow{4}{*}{ non-experts } & $\begin{array}{l}\text { no. of opened clues } \\
\text { in intuitive condition }\end{array}$ & & $\mathrm{r}=.255(\mathrm{p}=.341)$ \\
\hline & $\begin{array}{l}\text { no. of opened clues } \\
\text { in rational condition }\end{array}$ & $\mathrm{r}=.255(\mathrm{p}=.341)$ & \\
\hline & PID-I & $\mathrm{r}=-.680(\mathrm{p}=.004)$ & $\mathrm{r}=-.465(\mathrm{p}=.070)$ \\
\hline & PID-D & $\mathrm{r}=.269(\mathrm{p}=.314)$ & $\mathrm{r}=.538(\mathrm{p}=.032)$ \\
\hline
\end{tabular}

ber of assessed job applicants, which is a more valid characteristic than years in field. We expected that the score on the intuitive scale will affect the number of opened clues and that it will also be moderated by the recruiter's expertise. A model based on these presumptions for all respondents explained more than half of the variability in searching for information (Table 6). Deliberation as a predictor moderated by the number of selected job applicants was not significant in any of the tested models. We examined this model in a group of experts as well
(Table 6). This moderation analysis model has proven to be insignificant and explained smaller variability than the previous one.

The results of Study 2 have shown that people in the intuition condition really did engage in less information search (with no impact on their overall judgment, which did not differ between conditions), and, at the same time, revealed a slight tendency of intuitive people to look for less information. A tendency of deliberative people to look for more information was manifested only in the non-expert sample. 
Table 6. Moderation analyses in Study 2 - all participants and experts in intuitive condition

All participants, $n=31$. Moderation analysis in intuitive condition

PID-I = predictor, Number of assessed job applicants $=$ moderator, Number of opened cues without time stress $=$ outcome. Model parameters: $\mathrm{R}$ - squared $=.527 ; \mathrm{p}=.0001$; $\mathrm{n}=31 ; \mathrm{R}$ square increase due to interaction $\mathrm{R}^{2}=.0593 ; \mathrm{p}=.076$

\begin{tabular}{|l|c|c|c|c|}
\hline & Coefficient & SE & $\mathrm{t}$ & $\mathrm{p}$ \\
\hline Intercept - () & 7.847 & .815 & 9.621 & .000 \\
\hline Condition - X (PID-I) & -.105 & .028 & -3.785 & .001 \\
\hline & & & & \\
\hline $\begin{array}{l}\text { Moderator - M (number of } \\
\text { assessed job applicants) }\end{array}$ & -.003 & .001 & -3.045 & .005 \\
\hline Interaction X X M & .000 & .000 & 1.840 & .077 \\
\hline
\end{tabular}

Expert group, $n=16$. Moderation analysis in intuitive condition

PID-I = predictor, Number of assessed job applicants $=$ moderator, Number of opened cues without time stress $=$ outcome. Model parameters: $\mathrm{R}$ - squared $=.2180 ; \mathrm{p}=.3813$; $\mathrm{R}$ square increase due to interaction $\mathrm{R}^{2}=.1314 ; \mathrm{p}=.1811$

\begin{tabular}{|l|c|c|c|c|}
\hline & Coefficient & $\mathrm{SE}$ & $\mathrm{t}$ & $\mathrm{p}$ \\
\hline Intercept - (i) & 5.010 & 1.650 & 4.380 & .001 \\
\hline Condition - X (PID-I) & -.071 & .046 & -1.543 & .149 \\
\hline $\begin{array}{l}\text { Moderator - M (number of } \\
\text { assessed job applicants) }\end{array}$ & -.002 & .001 & -1.666 & .121 \\
\hline Interaction X X M & .000 & .000 & 1.990 & .181 \\
\hline
\end{tabular}

Legend: $\mathrm{SE}=$ standard error, $\mathrm{R}^{2}=\mathrm{R}$ squared, $\mathrm{p}=$ statistical significance

\section{DISCUSSION}

In Study 2 we confirmed the results of Study 1, that is, intuition condition leads to less information search in general, but also, preference for intuition (as a dispositional characteristic) is not a single predictor without a moderator. We also found a tendency of intuitive people to engage in less information search, as predicted by the Less is more heuristic. However, the most important finding is that we directly showed, as in the Study 1 , how preference for intuition is manifested differently in experts and non-experts. In the rational condition, when participants were encouraged to use as many clues as they needed, there was no difference between experts and non-experts (9 vs. 10.9 opened clues). However, when intuition was induced, experts relied on significantly less information than non-experts (3.3 vs. 5.1 opened clues).

Noteworthy is also the fact that the amount of information search increased in the rational condition for both experts and non-experts (in experts the increase was even bigger), but the overall evaluation remained al- 
most the same (5.8 vs. 5.1 for experts; 7.0 vs. 7.4 for non-experts). However, the evaluation of experts was more precise (lower evaluation was normatively more correct) and it had a tendency to be normatively better with more information, while there was an opposite trend in non-experts. Of course, it is impossible to draw any conclusions based on this statistically insignificant trend, but it points to the possible hypothesis, that experts would profit more from information search than non-experts.

Moderation analysis for all respondents in this study (Table 6) shows that in the domain of recruitment there is not really a strong interaction between the preference for intuition as a predictor and the number of assessed job applicants. Although the model for all participants explains more than half of the variability in the number of opened clues and is highly significant, the interaction is only close to significance and adds only a small increase of the explained variability. This is even better manifested in the model for experts, which is insignificant and so is also the interaction. There are a few reasons for these results. Firstly, probably the most important reason is the small number of participants. The second possible reason is that recruiting differs from financial domain, involving a specific interaction between preference for intuition and experience. This explanation could also be supported by the fact that the number of opened clues in the conditions designed to induce intuitive processing (time stress and instruction for using intuition) differed greatly between the two studies (12.85 out of 25 clues in Study 1 vs. 4.25 out of 25 in Study 2). It is probably easier, even for non-experts, to evaluate a domain related to interpersonal relationships (in which every human is sort of an "expert") than a highly abstract financial domain. The extent of domain-specific knowledge plays a crucial role in the feeling of correctness, which influences the use of Type 1 processes (Thomson, 2009) and can explain the different pattern of information search between the two domains. The results from Study 2 show that although both, the preference for intuition and experience, predict searching for less information in the recruitment domain, their interaction produces no effect compared to the financial domain.

\section{GENERAL DISCUSSION AND CONCLUSION}

Generally, our results indicate that situational manipulations, such as inducing time stress or giving instruction to think intuitively, affect information search more than preferred cognitive style and that it is necessary to examine intuition in context-specific tasks, as the experience plays a crucial role in searching for information when making a decision.

The results of Study 1 in the field of business management showed that although under time stress participants opened fewer clues, intuitive people did not differ from the deliberative ones in terms of their information search. For example, Sarmány-Schuller (2010) found that intuitive participants solved more tasks under time pressure than analytical ones, but it was not related to the correctness of the solution. Also, Westcott (1961) did not find any differences in correctness of the solution between participants preferring longer or shorter intuitive "leaps". Similarly, in our study intuitive people did not differ in correctness of the solution, but our focus was on the amount of information search when solving one single problem in 
contrast with Sarmány-Schuller's study. Unlike Westcott (1961) we identified participants as intuitive based on their scores in self-report measures.

Years of experience in the field in the expert group proved to be a significant moderator in the relationship where preference for intuition predicts number of opened clues. These results are in line with the review of Camarer and Johnson (1991) who found that experts search less. Search for information is less costly for experts than novices (e.g., Chase, Simon, 1973). In Study 2 we explored the differences in information search between experts and non-experts, but in different domains (HR vs. financial) and the results revealed a different pattern of information search between experts and nonexperts. It was probably caused by higher familiarity leading to pronounced feeling of correctness (Thomson, 2009) in the domain of dealing with people, but this assumption needs further examination.

In both studies we set out to examine whether manipulation with either time stress or instruction would lead to intuitive processing, which would lead to searching for less information. Both, time stress and explicit instruction, lead to searching for less information, either through intuitive processing (instruction) or probably due to detrimental effects of time stress. Hausmann, Horstmann, and Ryf(2010) recommend the use of several manipulations of intuition and point to the fact that although intuition is fast and it is marked by solving problems in less time, reducing time is often not the most suitable manipulation for inducing intuition. (For similar arguments see Zakay, 1993.) Furthermore, time stress affected experts and non-experts differently - it did not lead to opening fewer clues in the group of non- experts. Experts usually use more valid clues (Hanák et al., 2013), they utilize more previous knowledge, and they form a kind of diagnostic reasoning that match the clues in a specific case, so they need to search only for information relevant to the problem at hand (Camerer, Johnson, 1991).

We also speculated whether preference for intuition (as a cognitive style) would lead to less information search and we examined it with respect to expert and non-expert population in two domains (financial and HR). It seems that searching for information, when making decisions, is affected very little by the intuitive or deliberative cognitive styles, as the only predictors. Such results as ours further undermine the practical usability of some self-report measures of analytical/intuitive cognitive styles (for review of predictive validity of these measures see Hanák, 2013). Intuitive people do not seem to look for less information than deliberative people. However, the effect of intuitive cognitive styles is different across conditions and influences non-experts differently than experts - intuitive non-experts in Study 2 searched for less information and only in the intuitive condition.

Our last concern was with the moderator experience affecting intuitive people more in terms of searching for less information. We found that experience, when taken alone, explains only a little of the variability in information search. On the other hand, interaction of preference for intuition and experience in the financial domain produces a significant effect, however, its effect is probably domain-specific. Although a similar pattern was found in the recruitment domain, the interaction of preference for intuition with experience was much smaller and added only little to the explained variability. Intu- 
ition largely interacts with expertise and it is almost impossible to study intuition in a domain-general way, as is the case of the most self-reported measures. Moreover, each domain shows a different pattern of interaction of intuition with expertise depending on the specific knowledge needed, which further complicates the use of self-report measures and stresses the necessity to use domainspecific performance tasks in the study of intuition.

Received February 6, 2014

\section{REFERENCES}

Åstebro, T., ELHEDHLI, S., 2006, The effectiveness of simple decision heuristics: A case study of experts' forecasts of the commercial success of early-stage ventures. Management Science, 52, 3, 395-409.

BALLOVÁ MIKUŠKOVÁ, E., 2013, Intuícia: Dobrý sluha, zlý pán? In: R. Hanák, E. Ballová Mikušková, V. Čavojová, Rozhodovanie a usudzovanie IV. Aplikácie a limity intuície (pp. 3348). Bratislava: Ústav Experimentálnej Psychológie SAV.

BALLOVÁ MIKUŠKOVÁ, E., HANÁK, R, ČAVOJOVÁ, V., under review, Intuition versus deliberation: Psychometric properties of two self-reported scales. Journal of Personality Assessment.

BETSCH, C., 2004, Präferenz für Intuition und Deliberation. Inventar zur Erfassung von affektund kognitionsbasiertem Entscheiden. [Preference for Intuition and Deliberation (PID): An Inventory for Assessing Affect- and Cognition-Based Decision-Making]. Zeitschrift für Differentielle und Diagnostische Psychologie, 25, 179-197.

BETSCH, T., HABERSTROH, S. (Eds.)., 2005, Routines of decision making. London: Lawrence Erlbaum Associates, Publishers.

CAMARER, C.F., JOHNSON, E.J., 1991, The process-performance paradox in expert judgment: How can experts know so much and predict so badly? In: K.A. Ericsson, J. Smith (Eds.), Toward a general theory of expertise, prospects and limits (pp. 195-217). New York (USA): Cambridge University Press.
CHASE, W.G., SIMON, H.A., 1973, Perception in chess. Cognitive psychology, 4, 1, 55-81.

ČAVOJOVÁ, V., 2013, O racionalite intuície. In: R. Hanák, E. Ballová Mikušková, V. Čavojová, Rozhodovanie a usudzovanie IV. Aplikácie a limity intuicie (pp. 11-32). Bratislava: Ústav Experimentálnej Psychológie SAV.

DIJKSTERHUIS, A., NORDGREN, L.F., 2006, A theory of unconscious thought. Perspectives on Psychological Science, 1, 2, 95-109.

EPSTEIN, S., 2003, Cognitive-experiential self theory of personality. Comprehensive Handbook of Psychology, Vol. 5, pp. 159-184.

EVANS, J.S.B.T., 2009, How many dual-process theories do we need? One, two, or many? In: J.S.B.T. Evans, F. Frankish (Eds.), Two minds: Dual processes and beyond (pp. 33-54). New York, USA: Oxford University Press, 1 st edition.

EVANS, J.S.B.T., 2010, Intuition and reasoning: A dual-process perspective. Psychological Inquiry, 21, 4, 313-326.

EVANS, J.S.B.T., FRANKISH, F., 2009, Two minds: Dual processes and beyond. New York, USA: Oxford University Press, 1st edition.

GARCIA RETAMERO, R., DHAMI, M., 2009, Take the best in expert-novice decision strategies for residential burglary. Psychonomic Bulletin \& Review, 16, 1, 163-169

GIGERENZER, G., 2007, Gut feelings. London: Penguin Books.

HANÁK, R., 2013, Prediktívna validita dotazníkov merajúcich intuíciu PID, REI a GDMS. In: R. Hanák, E. Ballová Mikušková, V. Čavojová, Rozhodovanie a usudzovanie IV. Aplikácie a limity intuicie (pp. 101-130). Bratislava: Ústav Experimentálnej Psychológie SAV.

HANÁK, R., 2010, Expert differences in setting clues for personnel selection. In: Zborník príspevkov z medzinárodnej vedeckej konferencie Ekonomický a Sociálny Rozvoj Slovenska (pp. 233-240). Vysoká škola ekonómie a manažmentu verejnej správy v Bratislave.

HANÁK, R., SIROTA, M., JUANCHICH, M., 2013, Experts use compensatory strategies more often than novices in hiring decisions. Studia Psychologica, 55, 4, 251-263.

HAUSMANN, D., HORSTMANN, N., RYF, S., 2010, Methods for inducing intuitive and deliberate processing modes. In: A. Glöckner, C. Witteman (Eds.), Foundations for Tracing Intuition: Challenges and Methods (pp. 219-237).

HOGARTH, R.M., 2001, Educating intuition . Chicago, IL: The University of Chicago Press. 
KLEIN, G., 1998, Sources of power: How people make decisions. Cambridge, MA: MIT Press.

MYERS, D.G., 2002, Intuition: Its powers and perils. New Haven, CT: Yale University Press.

SARMÁNY-SCHULLER, I., 2010, Decision mak ing under time pressure in regard to preferred cognitive style (analytical-intuitive) and study orientation. Studia Psychologica, 52, 4, 285-290.

SARMÁNY-SCHULLER, I., BUKVAJOVÁ, V., 2013, Neistota - istota a dimenzie kognitívneho štýlu reflexivita - impulzivita pri rozhodovaní sa v časovom strese [Certainty - uncertainty and cognitive style dimension reflexivity - impulsivity in time pressure deision making]. In: I. SarmánySchuller (Ed.), Otázniky rozhodovania: teória, empiria, život. 31. Psychologické dni: zborník príspevkov (pp. 284-290). Bratislava: STIMUL.

SHANTEAU, J., 1992a, How much information does an expert use? Is it relevant? Acta Psychologica $81,75-86$

SHANTEAU, J., 1992b, Competence in experts: The role of task characteristics. Organizational Behavior and Human, 53, 252-266.
STANOVICH, K.E., 2006, Rationality and the Adolescent Mind. Psychological Science, 17, 1, i ii.

STANOVICH, K.E., 2011, Rationality and the reflective mind. New York, USA: Oxford University Press, 1 st edition.

THOMSON, V., 2009, Dual-process theories: A metacognitive perspective. In: J.S.B.T. Evans, F. Frankish (Eds.), Two minds: Dual processes and beyond (pp.171-195). New York, USA: Oxford University Press, 1st edition.

WESTCOTT, M.R., 1961, On the measurement of intuitive leaps. Psychological Reports, 684, 267274.

WESTCOTT, M.R., 1966, A note on the stability of intuitive thinking. Psychological Reports, 19, 194.

ZAKAY, D., 1993, The impact of time perception processes on decision making under time stress. In: O. Svenson, J. Maule (Eds.), Time pressure and stress in human judgment and decision-making (pp. 59-72). New York: Plenum Press.

\title{
KOL'KO INFORMÁCIÍ POTREBUJETE? INTERAKCIA INTUITÍVNEHO SPRACOVÁVANIA S EXPERTNOSŤOU
}

\author{
V. Č a vojová, R. H a nák
}

Súhrn: Intuícia sa zvyčajne pokladá za automatickú schopnost', no len málo výskumov sa doteraz venovalo jej priamej súvislosti s množstvom vyhl'adávaných informácií. V tomto článku prezentujeme dve štúdie skúmajúce dve rozličné domény (finančnú a personalistiku) a obsahujúce odlišné manipulácie (časový stres a inštrukciu). Hlavným ciel’om oboch štúdií bolo skúmat', či preferencia intuície (ako kognitívneho štýlu) bude viest' k menšiemu vyhl'adávaniu informácií u expertnej aj ne-expertnej populácie, so skúsenost’ami ako moderátorom, ktorý viac ovplyvní intuitívnych l'udí, aby hl'adali menej informácií. Vo všeobecnosti naše výsledky naznačujú, že situačné manipulácie, ako je navodenie časového stresu alebo inštrukcia na intuitívne uvažovanie, ovplyvňujú vyhl'adávanie informácií viac ako preferovaný kognitívny štýl a že je potrebné skúmat' intuíciu v kontextovo špecifických úlohách, ked’že skúsenost' hrá kl'účovú rolu vo vyhl'adávaní informácií pri rozhodovaní. 